\title{
Cikkismertetés: Nagy kulturális tőke = normál testtömegindex?
}

\author{
Article review: High cultural capital equal to normal body mass index?
}

Ismertető: $\quad$ Vitrai József $₫$

Ismertetett cikk: Oude Groeniger J, de Koster W, van der Waal J, Mackenbach JP, Kamphuis CBM, van Lenthe FJ. How does cultural capital keep you thin? Exploring unique aspects of cultural class that link social advantage to lower body mass index. Sociology of Health \& IIIness. doi: 10.1111/1467-9566.13120

Beküldve: 2020.07.19.

doi: $\quad$ 10.24365/ef.v61i4.611

Kulcsszavak: gazdaságpolitika; népegészségügy; hatás; szisztematikus áttekintés

Keywords: political economy; public health; impact; systematic review

\section{HÁTTÉR}

Az elhízásra hajlamosító élelmiszer-környezet, azaz az egészségkockázatot jelentő élelmiszerek hozzáférhetősége, megfizethetősége és láthatósága nem egyformán hat mindenkire. A társadalmi-gazdasági helyzet önmagában nem magyarázza azt a tényt, hogy az alacsonyabb státuszúak miért híznak el nagyobb eséllyel. A kulturális tőke, azaz az egyén kultúrához kapcsolódó erőforrásainak nagysága a tapasztalatok szerint általában alacsonyabb testtömeg-indexszel (TTI) jár együtt. A szerzők célja az volt, hogy meghatározzák és megvizsgálják a kulturális tőke azon jellemzőit, amelyek összefügghetnek a TTI-vel.

\section{MÓDSZER}

A neves szociológus, Bourdieu elméletéből kiindulva a kulturális tőke méréséhez a kutatók négy jellemzőt választottak: a kifinomultságot (refinement), a mértékletességet (asceticism), a változatosság kedvelését (diversity) és az önértékelést (reflexivity). A kifinomultság, ami az elmélet szerint a forma és a megjelenés értékelése a funkció és a tartalom felett, szerepet játszhat az éhséget hamar elverő tartalmas, nehéz ételekkel szemben a finom, könnyü, látványos ételek választásában, az ételkészítésben, az étkezés előkészítésében való részvétel kedvelésében. A mértékletesség, vagyis lemondás, önkorlátozás a kitűzött célok elérése érdekében, mely a kisebb mennyiségű fogyasztást, a tudatosan, kevéssé feldolgozott élelmiszerekből összeállított étrendet valószínűsíthet, és a testalkatot részesíti előnyben az ételek élvezetével szemben. A változatosság kedvelése, annak önmagában értékként kezelése a hagyományos, sokszor energiadús ételekkel szemben a különleges, esetleg egzotikus, többnyire alacsony energia tartalmú ételek választásában játszhat szerepet. Az önértékelés, ami tulajdonképpen a tapasztalatok egyfajta belső „párbeszéd" formájában való folyamatos elemzését és a következtések levonását jelenti, a tudatos, az egészség mellett a fenntarthatóságot és a klímaproblémát is figyelembe vevő ételválasztásban, a gyermekek táplálásában, ízválasztását befolyásoló nevelésében jelenhet meg. 
A jellemzők mérésére egy új kérdőívet fejlesztettek, amit a holland GLOBE 2011-2016 vizsgálatban próbáltak ki és alkalmaztak. Az étkezési szokásokra vonatkozó korábbi tapasztalatok alapján az általában vett kifinomultság mellé az élelmiszer-kifinomultságra (food refinement) továbbá a nem édes íz kedvelésére (non-sweet taste) vonatkozó kérdéseket is teszteltek. A kulturális tőke előzőkben leírt jellemzőin, valamint az antropológiai és szociodemográfiai adatokon kívül hagyományos módon is mérték a kulturális tôkét: egyfelől a kultúrához köthető otthoni tárgyak (könyvek, mútárgyak) számával, valamint az olvasás és kulturális események látogatásának gyakoriságával, másfelől az iskolázottság szintjével. Az elemzés során meghatározták a kulturális tôke új és a hagyományos módon mért értékei és a TTI közötti összefüggéseket.

\section{EREDMÉNYEK}

A hat új jellemző mérését célzó kérdőív kipróbálásának eredményei alapján végül az új jellemzők közül csak négy mérésére került sor a fő vizsgálatban: a kérdőív ugyanis csupán a mértékletességet, az általános és élelmiszer-kifinomultságot, valamint az önértékelést mérte megbízhatóan (ezekre a Cronbach alfa 0,67-0,77 volt). Alacsonyabb TTI-vel járt együtt a mértékletesség $(p<0,027)$, az általános kifinomultság $(p<0,011)$, és az önértékelés $(p<0,008)$ - kiszűrve valamennyi más tényező, beleértve a hagyományosan mért kulturális tőke hatását.

Ugyanakkor az élelmiszer-kifinomultság nem mutatott összefüggést a TTI-vel. A hagyományosan, tárgyakkal és tevékenységekkel mért kulturális tőke TTI-t csökkentő hatását több mint fele részben (52\%) a három új jellemző, a mértékletesség, az általános kifinomultság és az önértékelés együtte sen megmagyarázta. Az iskolázottság és a TTI kapcsolatában ez az érték csupán 38\% volt.

\section{MEGBESZÉLÉS}

A kulturális tôke és a TTI összefüggésének mintegy harmadáért felelős önértékelés a tapasztalatok szerint jórészt a gyermekkori szocializációval, a szülők kulturális tőkéjével függ össze. A mértékletesség a magasabb iskolai végzettséghez szükséges elkötelezettséggel, céltudatossággal, nagyobb önfegyelemmel, teljesítménycentrikussággal függhet össze. A korábbi kutatások magas szintû általános kifinomultságot a jobb szociális státuszban élőknél gyakrabban mutattak ki. Úgy látszik, hogy az önértékelés, a mértékletesség és a kifinomultság jobban jellemző a magas státuszúakra, és ezek az egyéni tulajdonságok növelik az alacsonyabb testtömeg valószínűségét, az elhízásra hajlamosító környezetnek való ellenállást.

\section{KÖVETKEZTETÉSEK}

A legtöbb országban még mindig az egészséges testsúly fenntartásának személyes felelősségét hangsúlyozzák, és előnyben részesítik az egyéni viselkedés változtatására irányuló ( $p l$ a tájékoztatásra és az oktatásra támaszkodó) beavatkozásokat a rendszerszintú beavatkozásokkal szemben (pl. a só- vagy cukortartalom csökkentése), még akkor is, ha az utóbbiak igazoltan hatékonyabbak és méltányosabbak. Ez hátrányosan érinti az alsóbb rétegek tagjait, akik olyan körülmények között nőttek fel, amelyek akadályozták a magasabb kulturális tőke kialakulását, amely lehetővé teszi az elhízásra hajlamosító környezetben való sikeres tájékozódást, viselkedést.

\section{TANULSÁGOK A HAZAI SZAKEMBEREK SZÁMÁRA}

A krónikus betegségek okozta magas társadalmi terhek miatt az egészséges táplálkozás előmozdítása elsőrendű népegészségügyi feladat Magyarországon. Emiatt fontos szem előtt tartani, hogy az élelmiszerkörnyezet mellett az egyének társadalmi-gazdasági helyzete erősen meghatározza az étkezési szokásokat. Az egészséget kockáztató magatartás hátterében nem csupán a szokásosan figyelembe vett rossz jövedelemi helyzet, az alacsony iskolázottság miatti tudatlanság áll, hanem - amint ebben a cikkben igazolták, - a kulturális tóke alacsony mértéke is. Az elhízásra hajlamosító környezetben ugyanis a neveltetés során kialakuló olyan tulajdonságokra is szükségünk van, mint a kifinomultság, a mértékletesség és az önértékelés. Ilyen tulajdonságok késztetnek minket tápanyagokban gazdag ételek mértékletes fogyasztására, és az alacsony tápértékű, 
magas energia tartalmú ételek kerülésére. Mivel az egészséges táplálkozás feltétele a támogató élelmiszerkörnyezet, a kielégítő jövedelmi helyzet, illetve az étkezési kultúra megfelelő szintje, ezért elengedhetetlen a népegészségügy más szektorokkal való, és a mainál jóval szorosabb, együttmúködése a különböző társadalmi csoportok egészségi hátrányainak enyhítése érdekében. A cikk tanulsága teljes összhangban van az egyenlőtlenségek alapvető okaira vonatkozó elmélettel ${ }^{1}$, miszerint azok a beavatkozások csökkentik hathatósan az egyenlőtlenségeket, amelyek nem igénylik az egyének saját erőforrásainak felhasználását (mint pl. a légzsák bevezetése a biztonsági övvel szemben, vagy a folsavas liszt árusítása a terhesvitaminnal szemben).

\section{HIVATKOZÁSOK}

\footnotetext{
${ }^{1}$ Csizmadia P. Az egyenlőtlenségek alapvető társadalmi okai és az elmélet alkalmazási lehetőségei az egészségügyi szakpolitikákban. Egészségfejlesztés, 2017;58(2):17-19. doi:10.24365/ef.v58i2.168.
} 